Trinity University

Digital Commons @ Trinity

Modern Languages and Literatures Faculty

Research

Modern Languages and Literatures Department

Fall 1996

\title{
Appropriation and Gender: The Case of Catherine Bernard and Bernard de Fontenelle
}

Nina Ekstein

Trinity University, nekstein@trinity.edu

Follow this and additional works at: https://digitalcommons.trinity.edu/mll_faculty

Part of the Modern Languages Commons

\section{Repository Citation}

Ekstein, N. (1996). Appropriation and gender: The case of Catherine Bernard and Bernard de Fontenelle. Eighteenth-Century Studies, 30(1), 59-80. doi:10.1353/ecs.1996.0043

This Article is brought to you for free and open access by the Modern Languages and Literatures Department at Digital Commons @ Trinity. It has been accepted for inclusion in Modern Languages and Literatures Faculty Research by an authorized administrator of Digital Commons @ Trinity. For more information, please contact jcostanz@trinity.edu. 


\section{Ppropriation and Gender: The Case of Catherine Bernard and Bernard DE FonTENELle}

\section{Nina Ekstein}

In 1757, Bernard de Bovier de Fontenelle, the well-known popularizer of scientific thinking, homme de lettres, and secretary of the Académie des Sciences, died just months shy of his hundredth birthday. In 1758, Volume 10 of Fontenelle's Oeuvres appeared, edited by Fontenelle's chosen literary executor, the abbé Trublet. Along with a number of other works, Volume 10 contains a tragedy dating from 1690 entitled Brutus. This play has had a complex and curious history. The year 1758 marks the first time that Brutus appears under Fontenelle's name, but hardly the last. In 1690, when the play was first performed and published, it appeared under the name of Catherine Bernard. The complicated tale of the fortunes of Brutus, the shift of attribution and the appropriations to which it has been subjected, tell us much about the literary culture of the eighteenth century, about the place of women writers in the ancien régime, and about how women's works have been arrogated by men.

Brutus deals with the Roman consul who has his sons put to death for their treasonous alliance with the overthrown king, Tarquin. The political plot is doubled by a sentimental one, with both sons in love with Tarquin's daughter. Staged by the Comédie-Française, Brutus was a great success for its day, with twenty-seven performances from December 18, 1690 to August 12, 1691, and sixteen more in the eight years that followed. ${ }^{1}$ Its critical reception was equally positive: Donneau de Visé

NINA ESKTEIN is Professor of French at Trinity University. She has published articles on Racine, Molière, Scarron, and Villedieu, among others, and is author of Dramatic Narrative: Racine's Récits. Her recent work focuses on literary portraiture and women playwrights of seventeenth-century France.

Eighteenth-Century Studies, vol. 30, no. 1 (1996) Pp. 59-80. 
marvels at Bernard's ability to "forcefully advance heroic sentiments and nobly uphold Roman character" and later calls Bernard "a dangerous rival for all those who have a stake in the theater."

Little is known about the author's life. Catherine Bernard was born in 1662 in Rouen; at some point she moved to Paris and earned her living by her pen. Raised a Protestant, she renounced her faith upon the revocation of the Edict of Nantes in 1685 . She never married, but was protected by wealthy patronesses who seemingly influenced her to adopt a devout way of life. By the turn of the century her name disappeared from public view, and she is believed to have died in 1712. More is known about Bernard's literary career, a career marked by diversity and success. She published her first novel, Fédéric de Sicile, in 1680, at the age of eighteen. She wrote three novellas, Eléonor d'Yvrée (1687), Le Comte d'Amboise (1689), and Inès de Cordoue (1696), as well as a short story, Histoire de la rupture d'Abénamar et de Fatime (1696); all four are subsumed under the general title, Les Malheurs de l'amour. Inès de Cordoue contains two fairy tales, "Le Prince Rosier" and "Riquet à la Houppe," making Bernard one of the earliest contributors to this popular genre. ${ }^{3}$ In the field of verse, Bernard won the Académie française prize for poetry on three separate occasions (1691, 1693, and 1697) and the prize given by Jeux Floraux de Toulouse three times as well $(1696,1697,1698)$. She wrote only two plays, Laodamie (1689) and Brutus (1690), both tragedies with successful runs at the Comédie-Française. Her works-poetry, prose fiction, and tragedy-were regularly anthologized in the collective volumes that appeared starting at the end of the seventeenth century, a clear sign of the high esteem in which they were held. ${ }^{4}$ Barred from the Académie française because of its rule admitting only men, Bernard was accepted into the Académie des Ricovrati de Padua in 1699 and given the name "Calliope the Invincible." With the exception of her first novel, she signed all of her works; Bernard's name, and her name alone, appears on the title pages.

In contrast to Bernard's relatively brief literary career (1680-1696), Fontenelle was a major public figure throughout almost his entire lifetime and was respected as one of the great luminaries of the French Enlightenment. He came to public attention at the age of twenty, his talents praised in the Mercure galant, the prominent Paris gazette of the period. ${ }^{5}$ Early in his career, he tried his hand at a number of literary forms, but found greater success in using his rhetorical skill at popularizing scientific ideas, as in the Entretiens sur la pluralité des mondes (1686). He showed himself to be an independent thinker in such works as L'Histoire des oracles (1686), a broad attack on superstitious beliefs, and L'Origine des fables (1724), an early study of comparative religion which was critical of the Catholic church. As the longtime secretary of the Académie royale des Sciences, Fontenelle became known as a historian and philosopher of science. In the field of mathematics, he was interested in the differential calculus of Newton and Leibnitz and even published an original contribution to the field. He also engaged in the literary debates of the time, taking a strong pro-modern position in the Querelle des Anciens et des Modernes. ${ }^{6}$

What then is the link between Fontenelle and Bernard, or more specifically between Fontenelle and the corpus of texts signed by Bernard? There is no evidence in any historical document that Bernard and Fontenelle knew each other. ${ }^{7}$ 
Nonetheless, a long tradition links them; Fontenelle is commonly believed to be Bernard's uncle or cousin, though the lack of hard evidence raises doubts. ${ }^{8}$ There may have been some ties between them since they both were from Rouen and eventually settled in Paris; moreover, Bernard's work is at times warmly acclaimed in the Mercure galant with which Fontenelle had strong connections. But even if we were to hypothesize a connection between the two authors, it would reveal nothing about Fontenelle's relation to the works bearing Bernard's name.

When these works appear in the late seventeenth century, there is no mention of Fontenelle's name; in fact the praise that Bernard receives as an author sometimes specifically calls attention to the fact that she is a woman. Donneau de Visé, in his review of Brutus, exclaims that "women today are capable of anything." In 1702, Marie-Anne Barbier, in the preface to her own tragedy, Arrie et Pétus, discusses the important women writers of the seventeenth century; among them we find Catherine Bernard and specific reference to her tragedies. ${ }^{10}$ Fontenelle himself explicitly credits Bernard with Eléonor d'Yvrée in an article appearing in the Mercure galant of September 1687. Discussing the fact that many of the authors of recent popular novels were women (although, ironically, he credits Segrais with La Princesse de Clèves), Fontenelle refers to Bernard while providing an explanation for this female success: "As most women have quite refined minds, they think and express themselves more precisely than men when they think well. This is what Mlle Bernard has done in the Malheurs de l'amour [the larger title for all of Bernard's prose fiction] which she has polished with all possible care." ${ }^{11}$ Thus Fontenelle, along with everyone else, credits Bernard with the works that she signed, and he does so in such a manner as to preclude male authorship. ${ }^{12}$

Any discussion of attribution inevitably involves the concept of authorship. What did it mean to be an author in the last years of the seventeenth century? To what extent was this concept different from ours? Roger Chartier has examined the different mechanisms-juridical, repressive, and material-fundamental for the invention of the author as we understand it. ${ }^{13}$ By the end of the seventeenth century, only the juridical mechanism-laws protecting authors' rights—was not solidly in place. Alain Viala, focusing specifically on seventeenth-century France, asserts that basic authorial rights were firmly established in the practices and attitudes of the late seventeenth century. ${ }^{14}$ Plagiarism was universally decried and accusations of this offense appeared frequently in the literary quarrels of the period. ${ }^{15}$ The laws, however, did not keep pace with general attitudes to a large extent because of Louis XIV's desire to limit the independence of authors in order to use them for his own purposes. ${ }^{16}$ In fact, it was not until the late eighteenth century that the law recognized an author's unqualified ownership of his or her text. ${ }^{17}$ And even then, as Hesse clearly indicates, because of the differences in legal status of men and women, women were not always granted legal rights over their own texts. ${ }^{18}$ Viala points out that an author in Bernard's position could only seek protection from plagiarism and theft by publishing and signing his or her own work, which is precisely what Bernard did. ${ }^{19}$ Thus Catherine Bernard, or any other author of the period, male or female, would have clearly regarded her works as her property. In this respect, despite the lack of legal protections, the seventeenth-century conception of an author did not differ substantially from our own. 


\section{I}

The first significant rumblings of a possible shift in attribution of Brutus from Bernard to Fontenelle occur only after 1730. Until that time, for a period of forty years, no other suggestion of collaboration or hidden authorship arose. The date is significant because it marks the appearance of Voltaire's own tragedy, Brutus. Voltaire returned from England in 1729 with a new play which he was eager to stage. He saw himself as the standard-bearer of authentic tragedy which, he believed, drew its source from ancient Greece and Rome. He thus placed himself in opposition to the camp of the Modernes, who believed that contemporary writers were more than the equal of the ancients and who thus rejected classical models for their works. Fontenelle was one of the leaders of the Modernes. He, along with La Motte and Crébillon, important writers of the day, opposed Voltaire's stance, and convinced the young playwright that plans were afoot to insure Brutus's failure if it were staged.$^{20}$ Voltaire consequently delayed having his tragedy produced onstage. Finally, in December 1730, Brutus was performed and received mixed reviews. ${ }^{21}$

In 1730 a new edition of Bernard's Brutus (Veuve P. Ribou) appeared, the second and last independent publication of the play under Bernard's name. We can speculate that the publicity surrounding Voltaire's play stimulated a market that the publisher sought to exploit for this earlier and perhaps almost forgotten tragedy. After Voltaire's Brutus appeared, Fontenelle remained on the offensive. Recalling this period, Voltaire later wrote: "the late Bernard de Fontenelle and his group asked our common friend Thiriot to warn me seriously not to write any more tragedies, telling him, in regard to Brutus in 1730, that I would never succeed at that profession." 22 In March of 1731 the Mercure de France published a long article whose author was identified only as a certain Madame la Comtesse de ... and which called attention to the extensive borrowing Voltaire had made from Bernard's Brutus. The Mercure galant also published a negative review of Voltaire's new tragedy and suggested that Bernard's version was superior. ${ }^{23}$ Critics speculate that Fontenelle may have been involved in the composition of one or both articles, but no proof exists. ${ }^{24}$

Thus Voltaire, who by all accounts was very attached to his reputation as a great dramatist, was attacked on two fronts. The existence of Bernard's Brutus threatened his reputation as a dramatic writer. Fontenelle and his allies criticized him for his neoclassical stance. Voltaire could hardly take any direct action against either of them: Bernard had been dead for almost twenty years, and Fontenelle was an elderly figure of veneration. Voltaire's relationship with Fontenelle, then seventysix years old and secretary of the Académie des Sciences, shows signs of the classic ambivalence found between symbolic fathers and sons. Voltaire respected his elder and yet at times both rejected his ideas and made fun of him. Micromégas (1752) exemplifies this ambivalence: casting Fontenelle in the role of the secretary of the Académie de Saturne, Voltaire gently pokes fun at him at the beginning but ends by seriously paying him homage. ${ }^{25}$ Similarly, Fontenelle was happy to sponsor and support this promising neophyte, but he also resented Voltaire's success and independence.

We may hypothesize that Voltaire, unable to attack either Bernard or Fontenelle directly, moved to conflate the two, initiating a gradual drift to credit 
Fontenelle with the Brutus that Bernard signed. Exactly how Voltaire may have gone about fostering such a transfer of attribution is not entirely clear, at least before 1751 . However, several facts are certain. First, Voltaire made precisely such a move when faced with a strikingly similar situation a few years later. In 1736 Voltaire published La Mort de César. The subject had been successfully treated by Marie-Anne Barbier in her 1709 version of the tragedy. Faced again with a female predecessor, Voltaire reacted by accusing Barbier, this time in the preface to his own play, of having written her Mort de César in collaboration with Fontenelle. The absurdity of this suggestion is obvious when we consider that no one else even suggests that Barbier had ever known Fontenelle. ${ }^{26}$ We also know that Fontenelle's name began to be associated for the first time with Bernard's theater in the 1730s. Such comments ranged from rumors of possible collaboration to bald assertions that Fontenelle wrote under Bernard's name. ${ }^{27}$

Voltaire himself apparently made no pronouncements concerning the authorship of the 1690 Brutus until 1751 when he published the "Catalogue de la plupart des écrivains français" (in his Le Siècle de Louis XIV). ${ }^{28}$ In the entry for Bernard, Voltaire says: "author of several plays, together with the famous Bernard de Fontenelle who wrote almost all of Brutus." He does not mention any other of Bernard's works; in fact the only other thing he has to say about her is: "It is worth noting that the Allegorical Fable of Imagination and Happiness, which was published under her name, was in fact written by the bishop of Nîmes, La Parisière, the successor of Fléchier." ${ }^{29}$ Voltaire's rhetorical strategy is revealing: he first places Bernard's authorship in doubt and then supports his assertion with an accusation of literary theft, thus making it more believable that she would have sought to deny Fontenelle proper credit. Voltaire's entry for Fontenelle is flattering and repeats the same assertion: "he helped Mlle Bernard with several plays." ${ }^{30}$

While Voltaire's attack on Bernard seems clearly motivated, the question remains why Voltaire would seek to credit Fontenelle with the play. I can suggest two possible explanations. On a personal level, perhaps Voltaire substituted Fontenelle for Bernard because he preferred to be seen as having taken a man's work as his model (and a man who in 1751 was highly respected). At the same time, Voltaire managed to flatter and perhaps even co-opt Fontenelle by suggesting that the latter was the true author of this successful tragedy which served as his inspiration. Doing so would render Fontenelle unlikely to assert Voltaire's dramatic heresy, placing them rather in the same dramaturgical camp.

Although the exact nature of Voltaire's involvement in the shift of attribution of Brutus can probably never be known, the performance and publication of his own Brutus marked the occasion of the first mentions of Fontenelle's name in conjunction with the play. The assertions grow particularly bold almost immediately after Fontenelle's death (1757) with the publication of the abbé Trublet's Mémoires pour servir à l'histoire de la vie et les ouvrages de Fontenelle (1759) and the appearance of Volume 10 of Fontenelle's Oeuvres (1758), edited by Trublet. The abbé Trublet was a devoted disciple to Fontenelle in his later years. Although some confusion exists concerning the exact nature of their relationship, ${ }^{31}$ Trublet's function was clear: he was to be, as François Moureau put it, Fontenelle's "infatuated biographer." ${ }^{32}$ The 
Mémoires he published in 1759 are based on lengthy conversations he had with Fontenelle over an extended period. To what extent these Mémoires may be called a collaboration, that is to what extent Fontenelle shaped their content and form, is not clear. It seems reasonable to surmise that Fontenelle's role was significant when one considers that portions of the Mémoires were published in the Mercure galant prior to Fontenelle's death ${ }^{33}$ Furthermore, the Mémoires, while originally published in Amsterdam in 1759, reappeared in 1761 as Volume 11 of Fontenelle's complete works, thus welded to Fontenelle's works rather than an outside commentary on them and their author.

It is in these Mémoires that we find a strong assertion of Fontenelle's role in Bernard's literary production, an assertion supposedly based on Fontenelle's own admissions:

He helped Mlle Bernard with several plays. ... Particularly with the tragedy entitled Brutus, staged in 1690; it is almost entirely the work of Mr. de Fontenelle. He perhaps had a role as well in the creation of Laodamie, staged the previous year....

He helped Mlle Bernard as well with most of her other works, whether in verse or in prose, and even with her three novels, Eléonor d'Yurée, Inès de Cordoue and Le Comte d'Amboise. He himself told me so and it is easy to recognize his hand in these works. ${ }^{34}$

The range of Fontenelle's domain is extended beyond the theater, while his precise role remains vague. Interestingly, as Trublet's Mémoires proceed, Fontenelle's role in Bernard's work seems to grow. Almost three hundred pages later, Trublet describes the situation in somewhat different terms: "Mr. de Fontenelle had at the very least a very large role in the creation of all of the works of Mlle Bernard, whether in prose or in verse; this is so in the case of her three novels (Eléonor d'Yurée, Le Comte d'Amboise, and Inès de Cordoue), her two tragedies (Laodamie and Brutus), especially the second of the two, and the poems and odes which were awarded prizes by the Académie Françoise and the Jeux Floraux." ${ }^{35}$ Thus Fontenelle's role which Trublet initially described as "helped" ("aida") has grown to "had at the very least a very large role in" ("avoit eu au moins une très-grande part"). In essence Trublet (and/or Fontenelle) lays claim to every literary success that Bernard had, leaving aside her first and less masterful attempt at fiction (Fédéric de Sicile) ${ }^{36}$ and any poetry that was not awarded prestigious prizes. There are several ways to interpret these statements in the Mémoires. Either what Trublet recounts is true, Fontenelle deliberately lied to Trublet, Trublet himself embellished certain rumors that we found to have appeared after Voltaire's Brutus was staged, or Fontenelle's memory had grown faulty with advanced age. ${ }^{37}$

These assertions of Fontenelle's major role in Bernard's works were seconded by the virtually contemporary move of publishing Brutus under his name. In 1758, Trublet brought out a tenth volume of Fontenelle's Oeuvres. In it, among other works, we find four plays, none of which had ever before appeared under Fontenelle's name: Psyché, Bellérophon, La Comète, and Brutus. This is a curious move, first because the plays are between 68 and 80 years old by 1758, and second because it seems clumsily obvious to lay claim to all four simultaneously. Although all 
but Brutus were originally published without an author's name, they had previously been ascribed to Thomas Corneille (Psyché and Bellérophon) and Donneau de Visé ( La Comète). However, the attribution of these plays to Fontenelle excited no comment at the time, perhaps because Catherine Bernard, Thomas Corneille, and Donneau de Visé were long dead, and these plays almost forgotten. ${ }^{38}$

As in the case of Trublet's Mémoires, Fontenelle's role in the publication of these four plays is not known. Did Fontenelle control the choice of what to include in this volume that appeared in the year following his death? Was the choice entirely Trublet's? If so, was it made on the basis of certain statements Fontenelle had made to him in their conversations? One curious feature of the appearance of this volume is the cleavage it operates in the body of work signed by Bernard. Brutus appears under Fontenelle's name ${ }^{39}$ Laodamie does not; nor do any of the works of fiction or poems that Bernard signed. The works of prose fiction as well as Laodamie all take women as their protagonists. Brutus, on the contrary, deals with a father forced to have his sons put to death for treason. Women do play a role in the attendant love plots, but they are clearly ancillary to the men in terms of the play's action. This superficial male-centeredness of the plot has facilitated, I believe, the attempt to transfer the attribution of the tragedy from a woman to a man. ${ }^{40}$ Ironically, the cleavage made in Bernard's works by Trublet may have undermined the transfer of attribution. With the exception of the work of Heidi Wolff, who focuses on Bernard's narrative fiction and not her theater, ${ }^{41}$ scholars have not divided the body of work in two, crediting Fontenelle with Brutus and Bernard with the other works. The entire oeuvre coheres, no doubt because of the unifying force of the single authorial signature.

Since Trublet's day, the issue has been the degree to which the entire group of works is to be ascribed to Bernard or to Fontenelle. Trublet's assertions in his Mémoires by no means settled the issue. In 1768 the Bibliothèque du théatre françois credits Bernard with Laodamie and Brutus, making no mention of Fontenelle. ${ }^{42} \mathrm{~A}$ year later the abbé de La Porte mentions Fontenelle's advice and guidance in conjunction with Bernard's works. ${ }^{43}$ This kind of uncertainty persists to our day, with scholars remaining divided on the subject. Credible and well-informed voices have spoken out on behalf of Bernard's sole authorship, while others have supported a significant role for Fontenelle. ${ }^{44}$ The question of "collaboration" has further confused matters. The term has often appeared in discussions of the authorial status of Bernard and Fontenelle since the mid-eighteenth century. In the total absence of any hard evidence, it is impossible to prove or disprove that collaboration between the two occurred. In fact there is no clear discussion of what such a collaboration might have involved or what form it might have taken. ${ }^{45}$ Instead, the suggestion of collaboration functions as the primary vehicle for introducing Fontenelle into the sphere of authorship. Because Bernard's signature is affixed to the works, scholars from Trublet to Niderst have been loathe to assert Fontenelle's unqualified, sole authorship. The term "collaboration" functions as a wedge, allowing Fontenelle's name to become affixed to the works as well. Thus the choice to suggest collaboration in the case of Bernard and Fontenelle becomes a move to give credit to Fontenelle. From there it is a simple matter to attribute the success of the work to Fontenelle's participation, slipping eventually toward a linguistic instability that favors Fontenelle with ever greater credit. A classic 
example of this phenomenon is the following statement made by Niderst, France's foremost scholar of Fontenelle: "The tragedies by Mlle Bernard and Fontenelle will show us how the philosopher judges the politics of the king." ${ }^{46}$ Similarly, Morel entitles his article, "Catherine Bernard and Fontenelle: the art of tragedy" ("Catherine Bernard et Fontenelle: l'art de tragédie"), but in fact he progresses quickly from discussing "les auteurs" to focusing strictly on Fontenelle as the author: "this young Tibérinus [a character in Brutus] is quite seductive for Fontenelle who knows what exquisite pleasure is, what fine food is, and how to live well; and these pure, virtuous Romans are for him, as well as for Tibérinus, it seems to me, horribly boring individuals." "47 Garavini sometimes refers to "the author" ["l'autore"] and at other times to "the authors" ["gli autori"].$^{48}$ In these examples, authorial identity is problematically unstable; it slips awkwardly between Bernard and Fontenelle.

The choice to assign credit to Fontenelle at times seems based on a high level of discomfort with female authors. Tragedy, after all, has historically been very much the domain of male writers. ${ }^{49}$ Brutus was a powerful, successful, classical tragedy. A deep-seated resistance to giving a woman author credit for such a work no doubt explains much of the questioning of attribution to which Bernard has been subjected. The idea that Bernard might have had a collaborator is an expression of the opinion that she was incapable of producing the literary text herself. Such accusations were common in the case of all women writers in the seventeenth and eighteenth centuries and almost universal when it came to women playwrights. ${ }^{50}$ Barbier, in her preface to Arrie et Pétus (1702), complained that women writers were regularly accused of having a male collaborator, particularly when the work in question was reviewed positively; she too was subjected to such accusations. ${ }^{51}$ The denigration of Bernard often has a distinctly gender-linked dimension. When one of her works is criticized, Bernard's name, and not Fontenelle's, is attached to it. Plusquellec, in her dissertation on Bernard, seems profoundly undecided about the issue of attribution; when she criticizes Laodamie, however, the play is clearly attributed to Bernard alone: "Mlle Bernard was perhaps mistaken in having centered her tragedy around the two sisters." ${ }^{52}$ Niderst too seems happy to give Bernard authorial credit while he criticizes the work: "the lines of verse written by Mlle Bernard remain somewhat cold and convoluted." ${ }^{33}$ When Niderst praises Brutus, Fontenelle's name precedes Bernard's, but when he finds the play less audacious than Voltaire's, Bernard's name comes first. ${ }^{54}$ In sum, if it's good, then Bernard probably didn't write it; if it's not, then perhaps she did. Marie-France Hilgar underlines the contradiction inherent in such a critical stance: "Let us note the ambiguity of literary criticism written by men which either finds the plays written by women to be mediocre or refuses to believe a woman capable of writing them." 55 Thus, while Bernard is sometimes credited with the works bearing her name, she is often simultaneously subjected to denigration. Her skill as a playwright is specifically assailed by the presence of frequent references to Corneille and Racine. Although Bernard was no doubt strongly influenced by her illustrious predecessors, such references tend to appear at the expense of any discussion of Bernard's plays themselves, listing similarities rather than considering Bernard's plays on their own terms. ${ }^{56}$ Furthermore, references to Racine and Corneille are not phrased so as to suggest intertextual enrichment, as well they might be, but function simply as a strategy to dismiss Bernard's theater as derivative. ${ }^{57}$ 
At times Bernard is simply dismissed in a fashion so cavalier as to suggest profound hostility. René Pomeau, in a published discussion following Morel's paper, argues the superiority of Voltaire's Brutus to Bernard's, while making it clear that he has not even read Bernard's play! ${ }^{18}$ Niderst, writing an entry on Bernard for the Dictionnaire des littératures de langue française, entitles the biographical section: "Une carrière banale" ["A banal career"]. He goes on to say: "A fundamentally rather banal career, one which can have little interest beyond its capacity to enlighten us concerning the condition of women, specifically the condition of women writers, at that time: influential allies (Pradon); an almost feverish level of activity (novels, tragedies, poems) encouraged by poverty; the recognition which accompanies literary awards; the protection of the king and certain ministers. Finally with success comes repentance, silence, and piety." ${ }^{59} \mathrm{His}$ dismissive, condescending tone is evident, but ironically what he describes does not seem "banale" at all..$^{60}$ In the case of Niderst as well, attacks on Bernard are almost invariably accompanied by arguments or mere assertions attributing Brutus and others of the works in question to Fontenelle.

Alain Niderst has played an active and influential role in discussions of the authorship of these works. He is, without a doubt, the foremost Fontenelle scholar in the world today. His two lengthy works, Fontenelle à la recherche de luimême (1972) and Fontenelle (1991), are the touchstones of modern Fontenelle studies. $\mathrm{He}$ is also, however, the most enthusiastic apologist and admirer of Fontenelle since Trublet. In his support for Fontenelle, he regularly alternates giving his man entire or partial credit for the works in question with remarks denigrating Bernard. He says that Bernard wrote Eléonor d'Yvrée "avec [with] Fontenelle," but then describes it on the following page: "this pre-Stendhalian psychological novel that he offers us." ${ }^{61} \mathrm{He}$ gives primary credit to Fontenelle for Laodamie, saying that he composed it "with the help of Catherine Bernard, who signed the play." ${ }^{62} \mathrm{He}$ denigrates Bernard by doubting the sincerity of the sentiments expressed in her poem, Que le roi seul en toute l'Europe, défend et protège le droit des rois, insinuating that the only reason she wrote it was because she needed money. ${ }^{63}$ Pierre Ronzeaud has noted "the annexationist tendencies of Alain Niderst." ${ }^{64}$ The latter goes so far as to quote a line from Bernard's signed preface to Brutus as though Fontenelle had written it. ${ }^{65}$ Niderst is also the first to suggest, in the absence of any historical indications whatsoever, that Bernard and Fontenelle may have been lovers, thus providing a convenient cliché for cooperation wherein possession of one sort implies possession of another. Piva summarizes Niderst's project very well:

In his attempt to define the ties which may have existed between Fontenelle and Catherine Bernard, A. Niderst . . . has not restricted himself to making the brilliant Rouen native the more or less selfinterested friend of Catherine Bernard, nor even her straightforward literary advisor. Rather he has chosen to integrate, in a progressively bolder fashion, the body of work published under the name of Mademoiselle Bernard into that of Fontenelle himself, so that one can no longer discern who is the veritable author. ${ }^{66}$

Niderst is currently in the process of overseeing the publication of the complete works of Fontenelle (Editions Fayard). While basing his text on the 1751-61 Oeuvres, he has made one significant change. Brutus no longer appears as one of Fontenelle's works 
(Psyché, Bellérophon, and La Comète still do). Instead Niderst places Brutus along with, and undifferentiated from, Bernard's other tragedy and her works of prose fiction, under the heading, Oeuvres écrites en collaboration avec Catherine Bernard.$^{67}$ By making this move, Niderst effectively enlarges Fontenelle's claims and simultaneously makes Bernard's identity as an author entirely dependent on Fontenelle. Nothing is credited to Bernard alone. ${ }^{68}$

\section{II}

Brutus as well as the other works bearing Bernard's signature have been the object of a long tug of war. As it currently stands, the issues of authorship and collaboration have not been entirely resolved. However, as the history of the claims of attribution made on Brutus for the last 300 years demonstrates, a series of more or less deliberate efforts were made to credit Fontenelle at Bernard's expense. Actually proving Bernard's authorship is a daunting task. Typically, studies dealing with attribution make a case to credit a specific author with an unsigned text. The situation we encounter in the case of Bernard is an almost ludicrous reversal. Here we are faced with a signed text, and there is no indication for a period of forty years after its publication that anyone else had a hand in writing it. And yet, because of the curious history of Brutus and the claims made upon it, we are faced with the necessity of proving that authorship ought to be ascribed to the person who signed the works. How does one proceed if the virtually universally accepted marker-the signatureis to be ignored? ${ }^{69}$

Canonical scholars make attributions on the basis of internal or external evidence. ${ }^{70}$ Internal evidence involves parallels drawn on the basis of both the similarities of ideas and of styles. It would be impossible to prove Bernard's authorship on these grounds, however, because Trublet and Niderst allege that Fontenelle had some role in writing every work that bears Bernard's signature. What text could possibly provide a basis for comparison? ${ }^{71}$ External evidence involves documents and testimony of various sorts, and of course the signature. Given how little is known about Bernard's life, it seems unlikely that further external evidence will arise to settle the issue. Canonical scholars find arguments based on both internal and external evidence to be the most convincing. In this case, both kinds of evidence are out of reach.

Given these limitations, I will argue the issue from a different perspective. I will use primarily external evidence, not to show that Bernard wrote Brutus and the other works she signed, but to argue that Fontenelle could not have done so. Although Fontenelle tried his hand at a broad range of literary projects in the first part of his career, only one tragedy bearing his signature was ever staged. Aspar was performed on December 27, 1680. Hoping to prove himself the equal of his famous uncles, Pierre and Thomas Corneille, Fontenelle instead missed the mark. His play was a complete failure (Louis Maigron describes it as a "resounding flop"), with only three performances and the dubious distinction of being known as the occasion that originated the French tradition of the sifflet (according to Racine, who, it must be noted, was hardly impartial)..$^{72}$ Fontenelle was crushed: he destroyed the manuscript, 
thus leaving no concrete basis upon which to make any comparison with Brutus. There followed a period of dramatic silence. Fontenelle's next work of certain attribution, an opera, Thétis et Pélée, appeared in 1689. Working in the style of Quinault, he depicted the love between a mere mortal and a goddess. Thétis et Pélée, with music by Collasse, was a success. A year later he wrote a second opera, but Enée et Lavinie (1690) received a disappointing reception. In 1692 Fontenelle wrote a heroic pastoral entitled Endymion for performance in a salon. This pastoral received little notice. Once again he was influenced by Quinault (specifically his Triomphe de l'Amour); in fact Niderst admits that in places Fontenelle goes so far as to literally copy his source. ${ }^{73}$ This then is the sum of Fontenelle's dramatic output for the seventeenth century. One successful opera libretto, and three relative failures, the most egregious of which being his sole attempt at tragedy. It is a pattern of dramatic experience inconsistent with Brutus and Laodamie, two resounding successes.

Later in life, during a period extending from 1720 to 1741 , Fontenelle wrote a series of six comedies and a tragedy which he did not intend for the stage and which he did not publish until 1751. His enduring bitterness concerning the public reception of his earlier plays is evident in his 1751 preface: "I enjoyed at that moment [while writing Idalie in 1720] a pleasure that authors who write for the public apparently never feel. I did not always have in front of my eyes the formidable, pitiless, barbaric public. I did not incessantly wonder with cruel anxiety: "Will they understand this?" "Will they like that? Am I not being too long-winded, too brief, etc.?" I wrote for myself alone, and in that situation an author is at ease and easily satisfied." ${ }^{74}$ Such acrimony seems to reflect the experience of failure, and perhaps particularly the failure of Aspar. It does not seem compatible with the acclaim accorded Brutus and Laodamie. Furthermore, the mere act of composing a series of plays that were not intended for the stage was highly unusual; it too bespeaks failure rather than the onstage success of the plays signed by Bernard. ${ }^{75}$ Other questions arise. Why would Fontenelle put his name to Thétis et Pélée and Enée et Lavinie at precisely the same time-1689 and 1690-when he does not sign Laodamie and Brutus? Supposedly he did not sign the last two because he was loathe to attach his name to a dramatic work which might once again leave him open to attack. ${ }^{76}$ Why a fear of ridicule in the domain of tragedy, but not in that of opera? ${ }^{77}$

The gradual and still incomplete transfer of attribution of Brutus and the other works from Bernard to Fontenelle is perhaps not an accident of literary history. It is possible that Fontenelle himself had a deliberate hand in assuming credit for these works. He was involved in a number of other cases of disputed authorship, particularly during the last few decades of his life, precisely the period when his name is first associated with the works Bernard signed. Psyché (1678) and Bellérophon (1679), both operas, appeared without an author's signature, but were universally believed to have been written by Thomas Corneille. As late as 1733 , in the Bibliothèque des thêatres, absolutely no mention is made of Fontenelle in conjunction with either of these operas. Yet claims of collaboration between Fontenelle and his uncle arose. The dispute concerning credit comes to a head in 1740, more than 60 years after Bellérophon was performed, when the Bolaeana, ou bons mots de M. Boileau was published. Boileau, a longtime enemy of Fontenelle's, is quoted as having said: "Every- 
thing in Bellérophon that is half-decent comes from me." ${ }^{78}$ Boileau goes on to explain that Thomas Corneille did such a poor job that Lully had him (Boileau) rewrite the entire work. Fontenelle was furious; he responded in an indignant letter which appeared in the Journal des Savants in 1741. In it, according to Maigron the longest letter Fontenelle ever wrote, ${ }^{79}$ he denigrates Boileau's role in the creation of the play and modestly describes his own as capital. ${ }^{80}$ Whether Fontenelle had a hand in the composition of these two operas is an open question, but as in the case of the works Bernard signed, the possibility does not even arise until many years after their appearance.

A third play of disputed authorship is La Comète which appeared in January 1681, that is, only one month after Fontenelle's debacle with Aspar! The play was produced under the name of Donneau de Visé, the editor of the Mercure galant and someone with whom Fontenelle had close ties; the published edition of this one-act comédie-ballet had no author's name attached to it. In 1733 the Bibliothèque des théâtres says that in 1726 Fontenelle was credited with a play entitled La Comète. ${ }^{81}$ In 1735 Godard de Beauchamps credits De Visé alone, as do the Frères Parfaict in $1748 .^{82}$ It is only after Trublet published this play in Volume 10 of Fontenelle's Oeuvres that the latter's authorship seems to have been seriously considered. In the 1768 Bibliothèque du théatre françois, the play is listed among Fontenelle's works. However, Trublet's handling of La Comète creates more questions than it resolves. The abbé reports a conversation with Fontenelle on the subject during one of the last years of his life: "He [Fontenelle] told me himself that he might well have written it, that he had some recollection of having done so, etc." ${ }^{83}$ Fontenelle seems less than perfectly certain. To this day critics remain divided. ${ }^{84}$

Another case of disputed authorship in which Fontenelle may have appropriated the work of a woman author involves the Recueil des plus belles pièces des poètes français depuis Villon jusqu'à Bensserade, a popular and influential fivevolume anthology which appeared anonymously in 1692 . DeJean notes: "Initially the anthology was generally accepted as d'Aulnoy's. Fontenelle's name was attached to it only later; even though no convincing reason for the change in attribution has ever been offered, it has gained wide acceptance." 85 The pattern of transfer of attribution is familiar. Although Trublet may not have been the source of the attribution to Fontenelle, it is in his Mémoires that we find the statements that are later cited as the "proof" of Fontenelle's authorship. Trublet asserts that Fontenelle is "certainement" the compiler of the Recueil, that he admitted as much to several old friends. The abbe also brushes aside attributions to d'Aulnoy, insisting that the work couldn't possibly be by a woman. ${ }^{86}$

These are not all, but merely the most striking, examples of disputes concerning authorship involving Fontenelle. Although the degree of Fontenelle's personal involvement is unclear in many of these cases, it does not seem implausible to imagine that he made certain statements that influenced a shift in attribution. Furthermore he had both the motive and the means to carry out such literary colonization on Bernard and others. We may theorize that Fontenelle's first motive involves old age and impending death. The ascension of Voltaire marked Fontenelle's gradual decline: by 1730, Fontenelle was old; although still respected, he was no longer at the 
center of intellectual and literary activity. We can only imagine his frustration in the last years of his life as his voice was heeded less and less, and death neared. Niderst points to 1751 as a significant moment: "Fontenelle, when he reached the age of 95 , seems to have set out to construct a monument that would perpetuate his fame." This "monument" includes the publication in 1751 of the six comedies and one tragedy he wrote between 1720 and 1741 . Their appearance at this late date suggests Fontenelle's preoccupation with posterity, as well as an apparent interest in amassing and publishing as much as possible before death overtook him. His need for selfaggrandizement is reflected in his preface where, while situating his dramatic works in relation to those of his contemporaries, he completely neglects to mention Marivaux, the most successful playwright of the first half of the eighteenth century. ${ }^{88}$ It is plausible that Fontenelle's effort to perpetuate his own glory extended to the preparation, in collaboration with Trublet, of the Mémoires that the latter published soon after Fontenelle's death. Faced with death and oblivion, Fontenelle may well have sought credit for works he did not write, particularly those that were not signed. Brutus, although it was signed by Bernard, occupied a privileged position for Fontenelle. With its themes of Roman virtue, law, and duty, it can be read as a symbolic replacement for Aspar. Tragedy carried more prestige at the time than any other form of literature. Brutus, a successful tragedy, was the play that Fontenelle wanted to have written in place of his own disastrous failure.

Motivated by the fear of death, by the desire for self-aggrandizement, and by a need to compensate for his shortcomings, and with others such as Voltaire suggesting that he was the author of Brutus, Fontenelle may have found the temptation to take credit for the play irresistible. Furthermore, two distinct sets of circumstances made it inviting and relatively easy for him to do so. First, unlike almost all of his contemporaries, he lived to be virtually 100 years old. Figuratively, he conquered time. To the conqueror go the spoils, specifically the opportunity to rewrite history. In his discussions with Trublet (or perhaps even with Voltaire), it was a simple matter for Fontenelle to exaggerate his role in the creation of Bernard's literary works. Having outlived everyone else concerned, he had little fear of contradiction. Fontenelle's longevity also explains why forty years elapsed before any link was made between Fontenelle and Brutus: by 1730 few of Bernard's contemporaries were still alive. Second, the protean nature of Fontenelle's literary, philosophical, and scientific production is such that his name was, and still is, a magnet for attributions of all sorts. For example, Garavini recently suggested that he may be the true author of the novel, $\mathrm{La}$ Duchesse d'Estramène, which is normally attributed to Du Plaisir; Marcel Langlois theorized that it was Fontenelle who in fact wrote La Princess de Clèves. ${ }^{89}$

Fontenelle thus had the means as well as the motives for taking credit for the works Bernard signed. Whether we conclude patronage gone awry, overzealous defenders of Fontenelle's glory, or deliberate theft, circumstances made it possible for Fontenelle to receive (take) credit. These circumstances extend to the political and ideological climate of the early to mid-eighteenth century. At that time, a general unease with women's political roles of power was widespread, a fact which had negative ramifications for women writers. ${ }^{90}$ Their works were progressively obscured. In her important recent book, Tender Geographies, Joan DeJean argues that the novel as a literary form was appropriated by men in eighteenth-century France 
and its female origins erased. ${ }^{91}$ Although the origins of tragedy in France are decidedly male, and women have known few successes on the French stage, we nonetheless find the same impulse of appropriation in the domain of theater. The case of Catherine Bernard, although unusual in its particulars, is not an isolated one, but part of a larger pattern regarding the male appropriation of texts obviously written by women.

\section{NOTES}

1. Henry Carrington Lancaster, French Dramatic Literature in the Seventeenth Century, Part IV, 2 vols. (New York: Gordian Press, 1966), 1:358.

2. Bernard "pousse avec force les sentiments héroïques et [sait] soutenir noblement le caractère romain;" he later calls Bernard "une rivale dangereuse de tous ceux qui s'attachent au théâtre." Mercure galant, December 1690, 287-89; August 1691, 3. All translations are my own unless otherwise noted.

3. Charles Perrault published his own version of "Riquet à la Houppe" several months after Bernard's appeared, leading to some speculation about plagiarism. See Jeanne Roche-Mazon, "De qui est 'Riquet à la Houppe'?" Revue des deux mondes (1928): 428-31, and Bernard Piva's introduction to Catherine Bernard, Oeuvres, 2 vols. (Paris and Fasano: Nizet and Schena, 1993), 1:43.

4. Roche-Mazon, 415n.

5. "M. de Fontenelle, who, at the age of twenty, possesses more knowledge than one ordinarily has at forty. ... He is from Rouen; he makes his home there, and several of our finest noblemen who have seen him here admit that it is tantamount to murder to leave him in the provinces. . . He values his great knowledge only insofar as he can avail himself of it as a gentleman. He has a quick, elegant, and delicate wit." [“M. de Fontenelle, qui, à l'âge de vingt ans, a déjà plus d'acquis qu'on en a ordinairement à quarante. ... Il est de Rouen, il y demeure; et plusieurs personnes de la plus haute qualité qui l'ont vu ici avouent que c'est un meurtre que de le laisser dans la province. . . . Il n'aime les belles connaissances que pour s'en servir en honnête homme. Il a l'esprit fin, galant, délicat"] (Mercure galant May 1677, 117-18).

6. Otis Fellows, entry on Fontenelle in The Encyclopedia of Philosophy, 8 vols. (New York: McMillan, 1967), 3:209; Leonard M. Marsak, Bernard de Fontenelle: The Idea of Science in the French Enlightenment (Philadelphia: American Philosophical Society, 1959), 5-8.

7. René Godenne (preface to Catherine Bernard, Les Malheurs de l'amour [Geneva: Slatkine Reprints, 1979], viii), Piva (23), and Perry Gethner ("Introduction" to Laodamie, in Femmes dramaturges en France [1650-1750] [Tübingen: PFSCL, 1993], 184) all point to this total absence of proof of any tie between them. Catherine Plusquellec's historical research led her to a similar impasse ("Qui était Catherine Bernard?" Revue d'histoire littéraire de la France 85 [1985]: 667-69).

8. The following suggest some blood relation: Eugène Asse, Une Nièce du Grand Corneille. Mlle Bernard, (Paris: La Revue Biblio-Iconographique, 1900), 1; G. Rouger, ed., Perrault, Contes (Paris: Garnier, 1967), 269-70; Roche-Mazon, 432; Fausta Garavini, "Bernard de Fontenelle et compagnie (Du Plaisir Catherine Bernard)" Paragone 23, (1972): 19; Jacques Morel, “Catherine Bernard et Fontenelle: l'art de tragédie," in Fontenelle. Actes du congrès tenu à Rouen, ed. Alain Niderst (Paris: PUF, 1989), 179; Charles Mazouer, "Le Brutus de Catherine Bernard et Fontenelle: la tradition de l'héroüsme," Etudes normandes 36 (1987):49. The generational indeterminacy (uncle/cousin) is curious: Fontenelle was only five years older than Bernard. Titon du Tillet suggests some relation of friendship between the two (Le Parnasse français [Paris: J. B. Coignard, 1732], 2:542; cited by Plusquellec, "L'Oeuvre," 6). Arsène Houssaye calls Catherine Bernard Fontenelle's "muse tragique" (Fontenelle. Sa Vie et ses oeuvres, par Voltaire, la Marquise de Lambert, Grimm, Garat, Sainte-Beuve, Arsène Houssaye [Paris: Didier, 1852], 23).

9. “Les dames sont aujourd'hui capables de tout." He goes on to praise her other works as well as Brutus: "Two years ago she [Bernard] had another play performed, entitled Laodamie, which elicited tears from all the tender hearts in the audience. She writes in prose with the same precision as she does in verse, and nothing is better thought out than the two novellas that she has given the public, one entitled Eléonor d'Yvrée and the other the Comte d'Amboise" ["Il y a deux ans qu'elle fit jouer une autre pièce appelée Laodamie, qui coûta des larmes à tous les coeurs tendres. Elle écrit en prose avec la même justesse 
qu'elle fait en vers, et il n'y a rien de mieux pensé que les deux nouvelles qu'elle a données a u public, l'une sous le titre d'Eléonor d'Yvrée et l'autre sous celui du Comte d'Amboise") (Mercure galant, December $1690,287-89$ ).

10. In Femmes dramaturges en France, 259.

11. "Comme la plupart des dames ont l'esprit très délicat, elles pensent et s'expriment plus finement que les hommes quand elles l'ont juste. C'est ce que Mlle Bernard a fait dans les Malheurs de l'amour qu'elle a travaillé avec tout le soin possible" (Mercure galant, September 1687, 324-25).

12. The closest that anyone has come to linking Bernard with Fontenelle in a document dated before 1730 is an épitre written by a certain Gacon in 1697 which contains a veiled reference to an anonymous galant currying favor with the Académie française on behalf of one of Bernard's poems:

Are you aware, Madamoiselle,

That many a rhymer is surprised

And seeks to pick a quarrel with you

About the prize that you have received.

Some, although these are the least sensible ones,

Seeing your verses full of brilliance,

Say that they were written with some beau

Who corrects your work.

As for me, I think that Apollo

Is the gentleman who inspires you,

And who, in your name, produces

The fine works that are so admired.

[Savez-vous bien, Mademoiselle,

Que maint rimeur est étonné,

Et cherche à vous faire querelle

Sur le prix qu'on vous a donné.

Les uns, et ce sont les moins sages,

Voient vos vers pleins de brillant,

Disent qu'avec quelque galant

Qui vous corrige vos ouvrages.

Pour moi, je pense qu'Apollon

Est le galant qui vous inspire,

Et qui produit sous votre nom

Les beaux ouvrages qu'on admire.]

Quoted by Plusquellec, "L'Oeuvre," 212-13. The galant in question would seem to be Fontenelle, and the satire goes on to accuse him of having influenced his fellow members of the Académie française in Bernard's favor. The reference in this satiric poem, however, is doubly imprecise: is the galant in question in fact Fontenelle, and what exactly is meant by "corrige"?

13. Roger Chartier, The Order of Books, trans. Lydia G. Cochrane (Stanford, Ca: Stanford Univ. Press, 1994), 59.

14. Naissance de l'écrivain. Sociologie de la littérature à l'âge classique (Paris: Minuit, 1985), 92.

15. Lignières accused Boileau of plagiarism, Scudéry accused Corneille, etc. (Viala, 92-93).

16. Viala, 103.

17. Carla Hesse, "Reading Signatures: Some Legal Contingencies of Female Authorship in France, 1750 to 1850 ," Critical Matrix, 2. (1986): 8-9.

18. Hesse, 12.

19. Viala 93. For further discussion of the question of authorship during this period, see Martha Woodmansee, "The Genius and the Copywright: Economic and Legal Conditions of the Emergence of the 'Author," Eighteenth-Century Studies 17 (1984): 425-48; Mark Rose, "The Author as Proprietor: Donaldson v. Becket and the Genealogy of Modern Authorship," Representations 23 (1988): 51-85; 
Carla Hesse, "Enlightenment Epistemology and the Laws of Authorship in Revolutionary France, 17701793," Representations 30 (1990): 109-37. At the root of much of the discussion about the author is Michel Foucault's “Qu'est-ce qu'un auteur?” Bulletin de la société française de Philosophie 44 (1969).

20. Alain Niderst, Fontenelle (Paris: Plon, 1991), 318. See also Jean Orieux, Voltaire, trans. Barbara Bray and Helen R. Lane (New York: Doubleday, 1979), 92.

21. Kenneth N. McKee reports 15 performances in the 1730-31 season, a number considerably lower than that of Bernard's Brutus. Voltaire's Brutus had its greatest success during the Revolution, when it was performed 144 times ("Voltaire's Brutus during the French Revolution," MLN 56 [1941]: 101).

22. "Feu Bernard de Fontenelle et compagnie prièrent l'ami Thiriot de [m']avertir sérieusement de ne plus faire de tragédies et lui dirent à propos de Brutus en 1730 que [je] ne réussirai[s] jamais à ce métierlà" (23 March 1763); quoted by Christiane Mervaud, "Voltaire et Fontenelle," in Fontenelle. Actes $d u$ congrès tenu à Rouen, ed. Alain Niderst (Paris: PUF, 1989), 318.

23. Gethner, "Notice" to Bernard's Laodamie, in Femmes dramaturges, 184.

24. Niderst, Fontenelle à la recherche de lui-même (1657-1702) (Paris: Nizet, 1972), 428, and Plusquellec, "L’Oeuvre," 145.

25. In Micromégas, Voltaire describes the secretary as "a man of much intelligence, but who in fact never invented anything, but rather explained very well the inventions of others, and who composed little poems and large calculations reasonably well" ["homme de beaucoup d'esprit, mais qui n'avait à la vérité rien inventé, mais qui rendait fort bien compte des inventions des autres, et qui faisait passablement de petits vers et de grands calculs"] (Romans et contes [Paris: Garnier, 1960], 98).

26. Gethner, "Introduction" to Arrie et Pétus, 249n.

27. Granet hinted that Bernard had written Brutus "guided in this work by a well-known intellect" ["guidé dans cet Ouvrage par un bel esprit connu"], clearly Fontenelle (Le Nouvelliste du Parnasse, ou Réflexions sur les ouvrages nouveaux [Paris, chez Chabert, 1731], 1:75); Titon du Tillet stated the following year: "M. de Fontenelle, among others, took pleasure in his friendship with this young lady [Catherine Bernard], and in helping her with his advice in the composition of her works" ["M. de Fontenelle entr'autres se fit un plaisir d'être en liaison d'amitié avec cette Demoiselle, et de l'aider de ses avis dans la composition de ses ouvrages"] (Le Parnasse Français [Paris: de l'Imprimerie de Jean-Baptiste Coignard fils, 1732], 542). The above are quoted by Piva, 25n. The Frères Parfaict reminded readers that the Supplément de Moréri suggests that Fontenelle had perhaps had some part in the composition of Laodamie and Brutus (Claude and François Parfaict, Histoire du théâtre français, 1734-49, 3 vols. [Geneva: Slatkine Reprints, 1967], 3:202). Godard de Beauchamps noted in 1735 that Fontenelle did not admit authorship of any of the plays that were being credited to him (Recherches sur les théâtres de France, 1735 [Geneva: Slatkine Reprints, 1968], 255). In a letter from Alexis Piron to the Marquis de Senan d'Orgeval on December 31, 1730, we find: "Let us come to the theater. There we will find onstage a tragedy by Voltaire entitled Brutus; he is the man who condemned his sons to death, a subject treated by Fontenelle under the name of a Miss Bernard some twenty years ago" ["Venons au Thêâtre. Il paraît une tragédie de Voltaire, intitulée Brutus, c'est celui qui condamna ses fils à mort, sujet traité par Fontenelle, sous le nom d'une Demoiselle Bernard, il y a quelque vingt ans"] (Lettres de Piron à diverses personnes, in Mélanges publiés par la Société des Bibliophiles français [1826], 4:150-51, quoted by Piva, 25n.). At the same time, however, Brutus continues to be attributed to Bernard. Brutus appears in the Théâtre français au recueil des meilleures pièces de théatre (Paris: P. Gaudouin, 1737) under Bernard's name, and the Bibliothèque des théâtres (Paris: Prault, 1733) credits Brutus to Bernard alone.

28. In fact, in his entire correspondence, Voltaire only mentions Bernard once. In a letter dated September 29, 1749 to Marie-Louise Denis, his niece and mistress, encouraging her playwriting attempts, Voltaire says: "Many women have written mediocre tragedies which were performed many times; the Barbiers, the Bernards, the Gomezes received applause, but are they held in high regard? You have what it takes to rival the greatest men in this field" ["Beaucoup de femmes ont fait des tragédies médiocres qui ont eu beaucoup de représentations, les Barbier, les Bernard, les Gomez ont été applaudies, mais quel cas fait-on d'elles? Vous avez de quoi vous égaler aux plus grands hommes dans ce genre"] (Correspondance, 13 vols. [Paris: Gallimard, 1975] 3:113).

29. "Auteur de quelques pièces de théâtre, conjointement avec le célèbre Bernard de Fontenelle qui a fait presque tout le Brutus." "Il est bon d'observer que la Fable allégorique de l'Imagination et du Bonheur, 
qu'on a imprimée sous son nom, est de l'évêque de Nîmes La Parisière, successeur de Fléchier" (Voltaire, Oeuvres historiques [Paris: Gallimard 1957], 1138-39). I have found no other reference to this Fable in connection with Bernard.

\section{0. "Il aida Mlle Bernard dans quelques pièces" (Voltaire, Oeuvres historiques, 1162).}

31. Niderst sees him as something of an opportunist (Fontenelle, 390), while one critic refers to him as Fontenelle's nephew (Robert Garapon in his edition of La Bruyère's Caractères [Paris: Garnier, 1962], $175 \mathrm{n}$.). There is a striking similarity between calling Trublet Fontenelle's nephew and calling Bernard his niece. It would be interesting to speculate on how the avuncular role differs from the paternal one. Fontenelle is not generally depicted as a father figure, but critics have been drawn to casting him in the role of uncle, in the absence of any historical reason to do so.

32. Fontenelle's "biographe éperdu d'admiration" ("Fontenelle auteur comique," in Fontenelle. Actes $d u$ Colloque tenu à Rouen, ed. Alain Niderst [Paris: PUF, 1989], 192). Louis Maigron describes Trublet as "biased and blinded on behalf of his hero" ["prévenu et . . . aveugle . . . en faveur de son grand homme"] (Fontenelle. L'homme, l'oeuvre, l'influence [Paris: Plon, 1906], 26).

33. According to the title page of the second edition of the Mémoires (Amersterdam: Marc Michel Rey, 1759).

34. "Il aida Mlle Bernard dans quelques Pièces. ... Sur-tout dans la Tragédie de Brutus, jouée en 1690; elle est presqu'entièrement de Mr. de Fontenelle. Peut-être eut-il aussi quelque part à Laodamie, jouée l'année précédante. Il aida aussi Mlle Bernard dans la plupart de ses autres Ouvrages, tant en vers qu'en prose, et même dans ses trois Romans, Eléonor d'Yurée, Inès de Cordoue et Le Comte d'Amboise. Il me l'a dit et il est bien aisé de l'y reconnoître" (Mémoires pour servir à l'Histoire de la vie et des ouvrages de Mr. de Fontenelle [Amsterdam: Michel Rey, 1759], 24).

35. “Mr. de Fontenelle avoit eu au moins une très-grande part à tous les Ouvrages de Mlle Bernard, tant en Prose qu'en Vers; à ses trois Romans; (Eléonor d'Yvrée, Le Comte d'Amboise, et Inès de Cordoue) à ses deux Tragédies (Laodamie et Brutus) sur-tout à la dernière; aux Poëmes et Odes couronnées par L'Académie Françoise et par celle des Jeux Floraux" (Mémoires, 301n.).

36. This novel is, however, the object of critical moves that closely resemble the ones we are discussing concerning Fontenelle. Bernard published Fédéric de Sicile in 1680. While the privilège was in Pradon's name, the editor's Avis au lecteur affirmed that the novel "comes from a person whose gender, youth and merit inspire feelings as tender as those she describes in her works. One will never accept, despite the fact that it is the truth, that this book represents the first effort by a seventeen-year-old young woman" [le roman "vient d'une personne dont le sexe, la jeunesse et le mérite inspirent des sentiments aussi tendres que ceux qu'elle écrit, et qu'on ne croira jamais, quoique ce soit la vérité, que ce livre soit le coup d'essai d'une jeune personne de dix-sept ans"] (quoted by Plusquellec, "L'Oeuvre," 15). Despite this rather explicit statement, Plusquellec feels that "so many fine qualities . . . lead us to believe that she must have received the aid of one or several individuals who are experienced writers; we find it difficult to believe, in fact, given her age, that she wrote this novel alone" [ "Autant de qualités . . nous inclinent à penser qu'elle dut recevoir le soutien d'une ou de plusieurs personnes rompues à l'art de la plume; nous avons, en effet, peine à croire, vu son âge, qu'elle ait écrit, de sa seule main, ce roman"] (33). Niderst too thinks that perhaps Pradon helped her write it (Fontenelle, 33).

37. Speaking of Fontenelle in his nineties, Maigron says: "his memory was also weakening; he had reached the point of forgetting even the titles of several of his own works" ["sa mémoire aussi s'affaiblissait; il en vint même à oublier jusqu'au titre de plusieurs de ses ouvrages"] (Fontenelle, 87).

38. Bernard died in 1712, Thomas Corneille in 1709, and Donneau de Visé in 1710.

39. It reappears in the 1761,1766 , and 1818 editions of Fontenelle's works as well.

40. In my “A Woman's Tragedy: Catherine Bernard's Brutus" (Rivista diletturature comparate e moderne 48 [1995]: 127-39) I attempt to show how classically male structures are in fact called into question in Brutus.

41. Das Narrative Werk Catherine Bernards (1662-1712) (Frankfurt: Peter Lang, 1990).

42. Bibliothèque du théâtre françois (Dresden: Groell, 1768). 
43. "It is claimed that M. de Fontenelle, attached to Miss Bernard through the bonds of friendship even more than those of family ties, contributed with his advice and his help to the success of her works" ["On prétend que M. de Fontenelle, que les liens de l'amitié, plus encore que ceux de la parenté, attachoient à Mademoiselle Bernard, contribua par ses conseils et ses secours, au succès de ses Ouvrages"] (Histoire littéraire des femmes françoises [Paris: Lacombe, 1769], 481).

44. To break down the field briefly, those who believe Bernard to be the sole author include the Frères Parfaict, Godard de Beauchamps, Lancaster, Piva, Henriette Goldwyn ("Catherine Bernard ou la voix dramatiqueéclatée," in Ordre et contestation au temps des classiques, ed. Roger Duchêne et Pierre Ronzeaud [Tübingen: PFSCL, 1992], 203-11), Gethner, Mazouer, Eugène and Emile Haag (La France Protestante [Paris: Sandoz et Fischbacher, 1879], and Van Eerde ("Le Théâtre de Fontenelle," Studi Francesi 6 [1962]: 279-83). Those who believe Fontenelle's role to be crucial are: Niderst, Morel, Pizzorusso (Il Ventaglio $e$ il compasso, Fontenelle e le sue teorie letterarie [Naples: Edizioni scientifiche italiane, 1984]), Maigron, and La Porte. Plusquellec and Cassin ("Catherine Bernard," Revue de Rouen et de Normandie [1845]: 228-31) remain undecided.

45. In contrast, Joan DeJean reconstructs a convincing collaborative context in the milieu of the seventeenth-century salon (Tender Geographies [New York: Columbia Univ. Press, 1991], 16 and 71-72).

46. "Les tragédies de Mlle Bernard et de Fontenelle nous montreront comment le philosophe juge la politique du roi" (Fontenelle à la recherche, 399; italics mine).

47. “Ce petit Tibérinus est bien séduisant pour Fontenelle, qui sait ce que c'est que la volupté, qui sait ce qu'est la bonne chère, qui sait ce qu'est le bien-vivre et ces Romains vertueux, purement vertueux, sont aussi, me semble-t-il, pour lui des gens horriblement ennuyeux" (187). Mazouer makes a similar move, but in the opposite direction, entitling his article "Brutus by Catherine Bernard and Fontenelle: the tradition of heroism," ["Le Brutus de Catherine Bernard et Fontenelle: la tradition de l'héroïsme"]. He completely dismisses Fontenelle in a single sentence on the first page, arguing that it impossible to know what Fontenelle's role was, and that in any case Bernard is the "principal author" ["auteur principal"] (49).

48. “Bernard de Fontenelle et compagnie," 36.

49. Carol Gelderman, “The Male Nature of Tragedy,” Prairie Schooner 49 (1975): 220.

50. Gethner, "Introduction" to Femmes dramaturges, 11. He points out how women writers, as opposed to males, were condemned for having a mentor: "furthermore, their detractors even dared to claim that these women were merely fronts for a male author, although they knew that these were nothing but lies" ["de plus, leurs détracteurs osèrent même prétendre qu'elles ne servaient que de prête-noms pour un auteur masculin, quoiqu'ils sussent que c'étaient de purs mensonges”] (11). All six of the women playwrights in his anthology (including Bernard) were subjected to such attacks.

51. Gethner, "Introduction" to Arrie et Pétus 249. Speaking of the reception of her tragedy in its preface, Barbier says: “As for the remainder [of the play], it was found to be quite good, and perhaps even better than I might have wished, for certain individuals took the opportunity to state that a woman was not capable of such success. In truth, I would have never believed that what was pleasing in my work would be detrimental to me, or that individuals of our sex would be denied the credit for producing fine things" ["A l'égard du reste on l'a trouvé assez bon, et peut-être meilleur que je n'aurais dû le souhaiter; puisque certaines gens en ont pris occasion de dire qu'une femme n'était pas capable de si bien réussir. En vérité je ne me serais jamais imaginé que ce qui a plu dans mon ouvrage, eût dû me nuire, ni qu'on refusât aux personnes de notre sexe le mérite de produire de bonnes choses"] (258).

52. "Mlle Bernard a peut-être eu le tort d'avoir centré l'intérêt de sa tragédie sur les deux soeurs" ("L'Oeuvre," 124). Niderst was the director of this dissertation, which may explain in part the indecision Plusquellec displays.

53. "Les vers de Mlle Bernard restent assez froids et contournés" (Fontenelle à la recherche, 449).

54. "No doubt he [Voltaire] recalled Shakespeare when he wrote it, and he especially could not have forgotten the Brutus by Fontenelle and Catherine Bernard that had such a great success" ["Sans doute s'y souvient-il de Shakespeare, il n'a pu surtout oublier le Brutus de Fontenelle et Catherine Bernard qui avait eu tant de succès"] (Fontenelle, 318). "He [Voltaire] seemed more bold than had been Catherine Bernard and Fontenelle, more intent in particular on retrieving the true grandeur of antiquity" ["Il semblait plus 
audacieux que ne l'avaient été Catherine Bernard et Fontenelle, plus désireux surtout de retrouver la véritable grandeur antique"] (323). We find a similar attitude in the case of Morel who gives primary credit to Fontenelle. However, when it comes to denigrating the plays, Bernard's name reappears: "The two tragedies signed by Catherine are fine exercises in what is already neoclassical rhetoric. It is hard to know whether the elements in it that surprise the spectator can truly touch him, for the spectator finds in this play, in the form of clichés, the motifs and devices of a theatrical tradition which was already past its prime" ["Les deux tragédies signées par Catherine sont de beaux exercices de rhétorique déjà néo-classique. On ne sait si ce qui surprend en elles pouvait véritablement toucher le spectateur, qui y retrouvait, à l'état de poncifs, les motifs et les procédés d'une tradition thêâtrale qui sans doute avait fait son temps"] ("Catherine Bernard," 185). Note that Morel refers to the author as "Catherine."

55. "Remarquons l'ambiguïté de la critique masculine qui, soit trouve médiocres les pièces écrites par des femmes, soit ne veut même pas croire une femme capable d'en produire" ("Les Tragédies de Catherine Bernard," in Continental, Latin-American and Francophone Women Writers, ed. Ginette Adamson and Eunice Myers, [Lanham: Univ. Press of America, 1990], 2:113). In a similar vein, we find an amusing eagerness to give Bernard credit for something that Fontenelle does not want to take credit for: the Relation curieuse de lîle de Bornéo (1686), an allegorical attack on the Roman Catholic Church. Bayle published it in his Nouvelles de la République des Lettres under Fontenelle's name, not having understood its satirical nature and thus the inherent danger for its author. Naturally Fontenelle refused to avow authorship. Despite strong testimony that Fontenelle was the sole author, certain individuals have tried to give Bernard full or at least partial credit. The reasons to attribute this work to Bernard are feeble: first, she was a Protestant (until a year before the Relation appeared); and second, the island described is one in which only women may rule. Thematic feminocentricity is reflexively coupled with a woman author. Never mind that Bernard never wrote anything satirical or polemic. Even after Niderst himself discovered a letter by Fontenelle that strongly implies the latter's authorship, he still says: "It is nonetheless not impossible that Catherine Bernard had some part in it" ["Il n'est pas impossible toutefois que Catherine Bernard y ait mis la main"] (Plusquellec reports Niderst's discovery in "L'Oeuvre," 35 . The quote is from Niderst's Fontenelle [100], published seven years after Plusquellec's dissertation).

56. An example of this is Morel, 185.

57. Mary Elizabeth Storer speaks of Bernard's "two heroic tragedies in the style of her uncle, the great Corneille" ("deux tragédies héroïques à l'imitation de son oncle, le grand Corneille") (La Mode des contes de feés 1685-1700 [Paris: Champion, 1928], 64]); Garavini says, albeit in the context of Bernard's novels: "the Cornelian temptation is persistent" ["la tentazione corneliana è persistente"] ("Bernard de Fontenelle," 37); Wolff finds strong echoes of Corneille in Laodamie (Das Narrative Werk, 19-20). Niderst speaks of her work as "reminiscent of Racine," and as containing "memories of Corneille" ["des reminiscences de Racine," "des souvenirs de Corneille"] (Fontenelle à la recherche, 428).

58. Pomeau is clearly familiar with Voltaire's Brutus. His ignorance of Bernard's version is obvious in the questions he poses. For example, he inquires: "Is there this character Aronce in the Brutus of Catherine Bernard?" ["Est-ce qu'il y a ce personnage d'Aronce dans le Brutus de Catherine Bernard?"] (Morel, 187).

59. "Une carrière, au fond, assez banale, qui pourrait n'avoir d'autre intérêt que de nous éclairer sur la condition des femmes, en particulière des femmes-auteurs, à cette époque: des alliés influents (Pradon); une activité presque fébrile (romans, tragédies, poèmes), qu'encourage la misère; la consécration des prix académiques; la protection du roi et des ministres; enfin, avec la réussite, le repentir, le silence et la dévotion" (Dictionnaire des Littératures de langue française 3 vols. [Paris: Bordas, 1984], 1:245).

60. In an amusing twist, Piva, a critic who supports Bernard's sole authorship, seems to respond to Niderst when he entitles a section of his own work on Bernard, " A brilliant and fruitful career" ["Une carrière brillante et féconde"] (30).

61. "Ce roman d'analyse préstendhalien qu'il nous propose" The "il" is of course Fontenelle (Fontenelle, 115-16). Italics mine.

62. "avec l'aide de Catherine Bernard, qui signa Laodamie" (ibid., 140).

63. "Still as poor as ever, Catherine Bernard took up poetry; she had hopes of academic awards or annuities. In 1691, she wrote a poem on the theme The king alone in all of Europe defends and protects the rights of kings. One can just imagine her sincerity" ["Toujours aussi pauvre, Catherine Bernard se donnait à la poésie; elle en espérait des récompenses académiques ou des rentes. En 1691, elle versifia sur 
le thème Que le roi seul en toute l'Europe, défend et protège le droit des rois. On imagine avec quelle sincérité"] (Ibid., 155).

64. "La tendance annexionniste d'Alain Niderst." This tendency is not limited to Bernard's works, but it would seem that she is singled out for denigration by Niderst. Ronzeaud goes on to say that Niderst "does not hesitate to reduce to nothingness the role of Fontenelle's "collaborators" in the case of works that were believed to have been jointly produced (Bellérophon for Thomas Corneille ... and especially the entire theater of Catherine Bernard, who is mistreated to the point of angering American feminists who admire her)" [Niderst "n'hésite pas à réduire à néant le rôle des «<collaborateurs»> de Fontenelle dans des créations que l'on croyait plus partagées (Bellérophon pour Thomas Corneille ..., et surtout l'ensemble du théâtre de Catherine Bernard, maltraitée à ameuter les féministes américaines qui l'admirent)"] (review of Niderst's Fontenelle in Cahiers du dix-septième 1 (1991): 302).

\section{Fontenelle à la recherche, 430 .}

66. "Dans sa tentative de définir les rapports qui auraient existé entre Fontenelle et Catherine Bernard, A. Niderst ... ne s'est pas limité à faire du brillant Rouennais l'ami, plus ou moins intéressé, de Catherine Bernard, ni même son simple conseiller littéraire; il a été amené à intégrer, de façon progressivement plus poussée, l'oeuvre qui a été publiée sous le nom de Mademoiselle Bernard, à celle de Fontenelle lui-même; si bien qu'on ne sait plus, à la fin, qui en est le véritable auteur" (Piva, 23-24).

67. Forthcoming in Volume 8 of Fontenelle's Oeuvres complètes, the first six volumes of which have already appeared.

68. Niderst, however, is not alone in publishing this group of texts. Piva is editing a two-volume, painstakingly detailed and annotated edition of Bernard's Oeuvres, giving full authorial credit to her. The first of the volumes, containing the works of prose fiction, appeared in 1993 (Paris and Fasano: Nizet and Schena). Gethner also published Laodamie under Bernard's name (Femmes dramaturges en France), and René Godenne published Eléanor d'Yvrée and Inès de Cordoue as hers as well (both Geneva: Slatkine Reprints, 1979).

69. Ironically, Fontenelle himself seemed to have found the authorial signature a reasonable basis for attribution; discussing his uncle's Agésilas, he said: "It must be believed that Monsieur Corneille wrote Agésilas, for his name appears on it" ["Il faut croire qu'Agésilas est de Monsieur Corneille, puisque son nom y est"] (quoted by André Blanc, "Fontenelle et le théâtre: une esthétique de mauvaise foi?" in Fontenelle. Actes du Colloque tenu à Rouen, ed. Alain Niderst [Paris: PUF, 1989], 171).

70. David V. Erdman and Ephim G. Fogel provide a thorough introduction to the issues involved in this type of criticism in Evidence for Authorship. Essays on Problems of Attribution (Ithaca: Cornell Univ. Press, 1966).

71. On the other hand, a number of scholars promote Fontenelle's claims on the basis of internal evidence, linking elements of the works signed by Bernard to ideas, theories, and even personal preferences of Fontenelle. Such arguments are often weak-trivial, insufficiently specific, highly limited in scope, imprecise-and thus unconvincing. To give only a few examples, Garavini finds a skepticism reminiscent of Fontenelle in Eléonor d'Yvrée (34); Plusquellec finds that the idea of retirement from the world as a condition for repos, as it is expressed in a nouvelle by Bernard, Histoire de la rupture d'Abénamar et de Fatime, reflects Fontenelle's fatalism at that time ("L'Oeuvre," 200); Niderst believes the themes of Inès de Cordoue to be similar to those of Fontenelle's Du Bonheur (Fontenelle à la recherche, 518); he sees Fontenelle's earlier obsessions with nature, love, and innocence reflected in Eléonor d'Yvrée (403). Niderst credits Fontenelle with the rigueur of Bernard's novels, the sarcastic and witty maxims in the Comte d'Amboise, and the large role of the peuple in Laodamie (Dictionnaire des littératures, 246; Fontenelle à la recherche, 409, 426). This is by no means a complete listing of the internal evidence that has been proposed to support Fontenelle's claims; curiously the arguments I have encountered rarely refer to Brutus. To the extent that one may be convinced by such internal evidence, however, it can do no more than suggest influence; it in no way proves authorship.

72. An "échec ... retentissant," (Fontenelle, 24).

73. Fontenelle, 159. He also says: "It is Quinault who is responsible for the only poetic moments of this pastoral: the Hymn to the Night and the Stars" ["C'est à celui-ci que sont dûs les seuls moments un peu poétiques de cette pastorale: l'hymne à la Nuit et aux Etoiles"] (Fontenelle à la recherche, 421). 
74. “Je goûtais alors une douceur qu'apparemment les auteurs qui se destinent au public n'ont jamais sentie. Je n'avais point toujours devant les yeux ce formidable, cet impitoyable, ce barbare public. Je ne me demandais point sans cesse avec une cruelle inquiétude: 'Entendra-t-on bien ceci? Goûtera-t-on cela? Ne serais-je point trop long, trop court, etc.?' Je n'écrivais que pour moi seul; et en ce cas-là un auteur est à son aise et aisément content" ("Préface générale des pièces suivantes," Oeuvres complètes [Paris: Fayard, 1993], 7-8).

75. Judgments of Fontenelle's literary talent both by contemporaries and by posterity, while they are in no way conclusive proof of anything, do little to make plausible Fontenelle's claims on the tragedies signed by Bernard. Voltaire points out that Fontenelle "did not have the talent of Pierre Corneille, his uncle, for the theater" [Fontenelle "n'avait pas le talent de Pierre Corneille, son oncle, pour le thêâtre"] (Fontenelle, sa vie et ses oeuvres, 5). La Harpe says: "M. de Fontenelle, worthy of respect in a number of areas, attempted almost all of the genres of poetry, because he had been born to succeed at none of them" ["M. de Fontenelle, estimable sans doute à bien des égards, a tenté presque tous les genres de poésie, parce qu'il n'était né pour aucun"] (quoted by Niderst, Fontenelle à la recherche, 167). Grimm is no more generous: "It is a matter of general agreement that he has wit and intelligence to the highest degree, but he is not considered to possess warmth, imagination, spontaneity, any variety of genius, or even talent" ["On convient assez généralement ... qu'il possède ce qui s'appelle le bel esprit au plus haut point, mais on lui refuse la chaleur, l'imagination, le naturel et toute sorte de génie, et même de talent"] (quoted by Niderst, Fontenelle à la recherche, 584). Moureau describes Fontenelle's eighteenth-century plays as resembling those of a "débutant"; Van Eerde finds that his dramatic works are clear evidence of the impossibility of substituting theory for genius; Maigron, describing Fontenelle's operas, says that they "were not worth much; it would be ridiculously easy to show that their author did not have and could not have the makings of a playwright" [Fontenelle's operas "ne valent pas grand'chose; et il serait trop facile de démontrer qu'il n'y avait pas chez son auteur, qu'il ne pouvait pas y avoir l'étoffe d'un poète dramatique") (Moureau, 199; Van Eerde, 280; Maigron, 23-24). Even Niderst, from whom we might expect every indulgence, admits: "Fontenelle was not really made for the theater" ["Fontenelle . . . n'était guère fait pour le théâtre"] (Fontenelle, 71).

\section{Niderst, Fontenelle à la recherche, 429 and Morel, 179.}

77. The contradictions extend to the level of content. Niderst reads Laodamie and Brutus as allegories for the political situation of England's James II; he is not daunted, however, by the potential contradiction in attitude found in Enée et Lavinie (1690; the same year as Brutus), where royal power is celebrated (Fontenelle à la recherche, 433).

78. "Tout ce qui s'est trouvé de passable dans Bellérophon, c'est à moi qu'on le doit" (quoted by Niderst, Fontenelle à la recherche, 96).

\section{Fontenelle, 22n.}

80. "With the exception of the prologue, of a famous passage which opens the fourth act: 'What a charming spectacle for my enamored heart,' of what is called the 'framework' in opera, and of little lines of verse tied to melodies and placed in the divertimenti, there can not be a single word of M. Despréaux's [Boileau] in the entire Bellérophon.... M. Lully asked M. Thomas Corneille to write an opera for him.... M. Corneille was not terribly fond of this kind of work; he had the idea of putting a young man living in the provinces in his place, without telling anyone. He sent him the framework, which had been shown to M. Despréaux and for which, it is true, he had suggested the name for the magician, Amisodar, a felicitous and sonorous choice. The young author carried out the entire project in his province.... The remainder of the play is his alone, except for certain indicated passages, and there is no evidence that M. Despréaux had anything whatsoever to do with those parts. Even if he claims categorically to have written those passages, anyone who is familiar with his style will not believe him... The play was sent to Paris act by act." ["A l'exception du prologue, d'un morceau fameux qui ouvre le quatrième acte: 'Quel spectacle charmant pour mon coeur amoureux' et de ce qu'on appelle dans les opéras 'canevas,' de petits vers faits sur les airs et qu'on met dans les divertissements, il ne peut y avoir un mot de M. Despréaux dans tout Bellérophon.... M. Lully pria M. Thomas Corneille de lui faire un opéra.... M. Corneille ne goûtait pas trop cette sorte de travail; il s'avisa de mettre en sa place, mais sans en rien dire, un jeune homme qui était en province. Il lui envoya le plan de Bellérophon, qui avait été montré à $M$. Despréaux et où il est vrai que le nom du magicien Amisodar, qui est heureux et sonore, fut fourni par lui. Le jeune auteur exécuta tout 
le plan dans sa province... . Tout le reste est de lui seul, hormis les endroits qui ont été marqués; mais il n’y a nulle apparence que M. Despréaux ait eu la moindre part à ces endroits-là; et quand il les revendiquerait positivement, on ne le croirait pas si l'on connaissait son style... . La pièce fut envoyé de province à Paris acte par acte"] (quoted by Niderst, Fontenelle à la recherche, 96-97).

81. Note the late date of the attribution. Curiously the Bibliothèque goes on to state that the arrival of Newton's comet in 1680 had given rise to two plays, one by De Visé and one by Fontenelle. To our knowledge, there exists in fact only a single play.

82. Beauchamps, 235; Parfaict, 3:192.

83. "Il m'avait dit lui-même qu'il pouvait bien l'avoir faite, qu'il en avait quelque idée, etc." (Mémoires, 90-91). When Trublet publishes La Comète in Fontenelle's works, he states categorically in a footnote: "This comedy is certainly the work of Mr. de Fontenelle" ["Cette comédie est certainement de Mr. de Fontenelle"] (Mémoires, 43). However, on the same page he refers to the play's author as "Mr. de Visé ou [or] Mr. de Fontenelle." Finally Trublet credits De Visé with several comments in the play which he finds to be of questionable taste.

84. In a similar vein, authorship of two plays, La Pierre philosophale (1681) and Les Dames vengées (1695), is discussed by Niderst. Both were originally attributed to a collaboration between Thomas Corneille and Donneau De Visé. Niderst expands the collaboration to include Fontenelle (Fontenelle à la recherche, 26 and 396); later, in the Dictionnaire des littératures de langue française, Niderst credits Fontenelle alone with La Pierre philosophale. Given the fact that no one seems to have mentioned Fontenelle's name in conjunction with these plays before Niderst, Fontenelle in no way himself influenced this particular shift in attribution.

85. DeJean, 184. D’Aulnoy is Marie-Catherine Le Jumel de Barneville, Comtesse d'Aulnoy (1650$1705)$, best known for her fairy tales and memoirs.

86. Mémoires, $74 \mathrm{n}$. and $72-73$.

87. "Fontenelle qui atteint quatre-vingt-quinze ans, semble s'attacher à s'édifier un monument qui perpétue sa gloire" (Fontenelle, 386).

88. Noted by Moureau, 192.

89. Garavini, 29; Langlois, "Quel est l'auteur de La Princesse de Clèves?” Mercure de France, 15 (February 1936), 58-82.

90. DeJean traces the development of the canon as a pedagogical tool to precisely this period. Batteux's 1747 Cours de belles-lettres focuses on texts that exemplify male values; he cites women authors (rarely) only to show how soft and inadequate they are in terms of "vigorous male Christian standards" ("Teaching Frenchness," French Review 61 [1988]: 403).

91. "The long-term relation between gender and the rise of the novel thus would seem to have been a casebook study in appropriation: men of letters co-opted the genre as soon as it achieved prominence. For example, in a 1779 eulogy of Voltaire, whose place in the Académie Française he was taking, Jean-François Durcis said of his predecessor that he had 'taken the empire of the novel from women'" (Tender Geographies, 163). 